\title{
Business Inefficiencies and Youth Unemployment in Ethiopia: A Case Study of Mettu Town
}

\author{
Satya Narayan Singh
}

$\mathrm{PhD}$, Associate Professor, Department of Economics, Faculty of Business and Economics, Mettu University, Mettu, Ethiopia

\begin{abstract}
This paper summarizes the arguments and counterarguments within the scientific discussion on the issues of unemployment in Ethiopia. The main purpose of the research is to examine the trend and determinants of unemployment in context of the inefficient manner of business in Ethiopia particularly in Mettu Town. The other specific objectives are to examine the current situation and trends of unemployment, to examine socioeconomic characteristics of unemployment and to identify the major factors that are responsible for unemployment in Mettu town of Ethiopia. Systematization of literary sources and approaches for solving the problem has widely been used that indicates that there is a contradictory scalier of unemployment in Ethiopia. The relevance of the decision of this scientific problem is how population growth, urbanization, and higher education increase unemployment in the country during the adoption of new business policy. Investigation of the unemployment topic in Ethiopia in the paper is carried out in the following logical sequence measuring the population growth; urbanization and education, which have an impact on unemployment. Methodological tools of the research methods were comparative analysis using statistical tools and techniques used in years of research 2018-2019. The object of the research are the regions specified systematically because namely they were elaborated. The paper presents the results of an empirical analysis of the unemployment trend and its determinant, which showed that there is a contradictory paradox among parameters. The research empirically confirms and theoretically proves that unemployment, particularly among youth, is creeping ahead in the region because of population growth, rapid urbanization and business inefficiencies as well. The results of the research can be useful for policymakers, academicians and researchers.
\end{abstract}

Keywords: unemployment, population growth, business characteristics, gender gap, training and capacity development programmes, business policy and business inefficiencies.

JEL Classification: E24, J11, M2, H21.

Cite as: Singh, S. N. (2019). Business Inefficiencies and Youth Unemployment in Ethiopia: A Case Study of Mettu Town. Business Ethics and Leadership, 3(2), 93-106. http://doi.org/10.21272/bel.3(2).93-106.2019.

(C) The Author, 2019. This article is published with open access at Sumy State University.

\section{Introduction}

\subsection{Background of the study}

Youth unemployment and underemployment are growing concerns worldwide. According to the International labor organization (ILO) estimates the youth in 2002 made up $41 \%$ of the worlds employed and 88 million people in absolute number. A young worker everywhere invariably has a higher rate of jobless and lower earnings than older workers do. In many concern, young people are also concentrated in low skill informal work or in hazardous form of work that are ill-suited to their age and experiences. Employment outcomes are typically the worst for former child labors and other early school leavers, the group, which has the least opportunity to accumulate the human capital needs for gainful full employment (Guaello Rosati et al., 2007). According to 2008 global employment trends for youth report prepared by the International Labour Organization in 2008, in the decade between 1997 and 2007 the unemployment worldwide increased from 10.9 to 11.9 percent while the global adult employment ratio stayed at the level of $4.2 \%$ from 1997 to 2007 . Today's world contains an estimated 1.2 billion young people aged between 15-24 years (an increase of 17\% compared to 1995), that is $24.7 \%$ of the world is working age population (Ilo, 2008). According to David Bell world growth unemployment rate in the year 2009 examines that Spain has 11.4\%, Denmark - 3.3\%, Mexico $-3.2 \%$, Canada $-2.8 \%$, United Kingdom $-2.7 \%$, Japan $-1.7 \%$ and Italy $-1.5 \%$ (Bell Blanch Flower, 2010).

The youth population in Ethiopia is projected to grow in absolute terms from about 15 million in 2005 to 26 million into 2013 but would remain at about one-fifth of the overall population during this period (CSA, 2005). The absolute size of the national labor force was estimated 32.2 million people in 2005 up from in estimated 
ISSN (online) - 2520-6311; ISSN (print) - 2520-6761

1.9 million people in 1984. Most of the young workers of Mettu Town are engaged in the agriculture sector, as they are unemployed in other sectors. It is found that the female workers are more employed in relatively informal sector as compared to their male counterparts. In 2006, E.C approximately, 71 percent of female particularly government employees were earning even less than one thousand birrs per month. However, about $82 \%$ of the male employees of the same sector, viz. government, were earned comparatively more. In addition, at a glance, the level of education of government employees was very high and the female educated was restricted only to secondary school (Mettu youth office, 2007). Employment protection legislation may play a pivotal role to provide employment opportunities but neither study finds a significant role for Employment Protection Legislation (EPL) per se. The comprehensive study of the role of institutions on employment patterns undertaken by Bassanini and Duval (2006), on the other hand, find a role for EPL in depressing youth employment rates, but, in contrast to Jimeno and Rodriguez-Palenzuela (2002), they also find a positive impact of youth minimum wages on youth employment. Jimeno and Rodriguez-Palenzuela (2002) and Bertola et al. (2007) find a role for unionization rates in reducing youth employment.

\subsection{Statement of the problem}

Nowadays, so many problems have been seen in the world. Especially the growth of population and unemployment is the main problem. This problem increases without an improvement in development. Population growths have a great impact on the expansion of unemployment worldwide particularly the youth unemployment is high, that is almost three times higher than the adult unemployment rate (ILO,2008). Moreover, the young people made up of $13.7 \%$ of the world total unemployed population despite accounting for only $25 \%$ of the working population (Pilgrim, et al., 2009). Today many of the developing countries are plagued by a historical unique combination of a massive rural to urban movement, stagnating agriculture productivity and growing urban and rural unemployment and under-employment. The challenge of youth unemployment in Africa is especially large. In Sub-Sahara Africa, youth people aged 15-24 account for 36\% of the working age group population. Due to population pressure, the number of young people looking for work is expected to increase by $28 \%$ in the next 15 years, equivalent to about 30 million people. Failure to address the youth employment issues will have serious consequences for the economy as well as society. Without the opportunity for young people to earn a living inter-generational cycle of poverty will persist, further affecting already made vulnerable by HIV/AIDS, food security, and violence (Guar Cello Rosati, et al., 2007). During the last decades, the youth population grew faster than the total population and youth employment. The share of the youth who are employed in youth population decline from $49.2 \%$ to $4.5 \%$ between 1997 and 2007 and the total number of unemployed persons increases from 63 million to 71 million between 1997 and 2007, in particular Sub-Saharan African the figure is estimated 8 to 10 million (Pilgrim, et al., 2009). Recession is also one of the problems of youth unemployment as it is regularly and reasonably argued that young people have been particularly hard hit by the recession; less reasonably, however, this assertion is often based on the changes, which have occurred in youth unemployment rates. Labour market experiences, including spells of unemployment, early on in a person's working life are likely to have repercussions which will be felt throughout their adulthood (O'Higgins, 2001). Analyzing the recent recession, O'Higgins (2012) found that the aggregate demand induced youth employment loss arising from the recession was reduced in countries with stronger not weaker employment protection legislation. In the context of the current prolonged recession, this creates the spectre of a lost generation of young people who become permanently excluded from productive employment (Scarpetta et al., 2010).

High level of unemployment and development is one of the critical socio-economic problems facing by Ethiopia. While the labor force grew with an increase in the proportion of youth employment growth that is inadequate to observe in labor market entrants. As a result, youth are especially affected by unemployment. Moreover, the youth are likely to be employed in the job of low quality, underemployed, working long hour, for a low wage, engage in dangerous work or receive only short term and informal employment arrangements (Dominic Barton, et al., 2013). In South Africa, about 42\% of young people under the age of 30 are unemployed, comparatively less than $17 \%$ of the adults over 30 years of ages. This is particularly the case for Ethiopia, which is a home to one of the largest youth population in Sub-Saharan Africa. The lack of employment opportunities for Ethiopian young people is a critical challenge for the development of the country; also one of the key barrier toward the millennium development goal. About $40 \%$ of Ethiopian completes primary education and just 13\% enrolled for secondary education, it means that the youngest people entering the labor market bring with them a very low level of human capital (World Bank, 2004).

Similarly, the problem of youth and unemployment is also common in the Mettu Town and it has reached at a notable level. In 2008, Mettu Town had a young population of 2010 and working age population are around 
1800. However, the unemployed young people are 210. There are many studies that investigate the same problem in the town (Mettu youth office, 2007).

\subsection{Objective of the study}

\subsubsection{General objective of the study}

The general objective of the study would be to examine the determinants of youth unemployment in Mettu Town.

\subsubsection{Specific objectives of the study are as follows:}

To identify the current situation and trend of unemployment.

To define strategies for further development.

To identify the socio-economic consequences of youth unemployed.

\subsection{Research question or hypothesis}

What are the determinants of youth unemployment?

How to identify the current situation and trends of unemployment?

What are the characteristics of youth unemployed in the socio-economy?

What are the strategies for further development?

\subsection{Significance of the study}

The socio-economic consequences that arise in association with high and growing youth unemployment would be cited. The present study would focus the youth unemployment which is the main problem/hurdle of a rapid development of the economy. Therefore, such a study may be helpful for policymakers and other concerns to adopt the policy for reducing unemployment. The study also contributes to the process of some selected respondents those who are not interested to give any information partly or fully. Solving the youth unemployment problem in Mettu Town thus provides an important platform to add additional knowledge on the existing literature to identify youth unemployment problem at the grassroots level.

\subsection{Scope of the study}

The study is conducted in Mettu Town that is the capital city of the southwest. This study has been conducted to area specific and analysis is based on a random sample and stratified technique. However, the primary data collected only from unemployed people in the Mettu Town provide a clear spectrum of unemployment in the country.

\subsection{Limitation of the study}

This study is also not away from limitations and the researchers faced any constraints although the study has a significant conclusion. The major constraints are as the study is based on small sample size due to lack of finance; the shortage of time also one of the constraints including the absence of appropriate data; and the careless response of the respondents.

\section{Review of Literature}

\subsection{Theoretical review of literature}

\subsubsection{Definition of basic terms}

The term unemployment was defined in many different ways by different Economist. Unemployment jobs situation in which people are qualified for a job willing to work and willing to accept the ongoing to wage rate but could not find jobs without considerable delay of time. Unemployment is the macroeconomic problem that affects people most directly and severely. For most people loss of a job means a reduced living standard and psychological disasters. A person is unemployed if he is currently available for employment and has actively looked for a job within the past four weeks. If unemployed workers have unable to find a job for so long that he finally gives up lope to get one he drops out of the labor force and is no without looking for a job such a person is called a discourage worker if some time later new opportunities come out, he may be stimulated again try to his chances thereby re-entering the labor force. Unemployment or joblessness occurs when people are without work and actively seeking work. The unemployment rate is admeasuring of the prevalence of 
ISSN (online) - 2520-6311; ISSN (print) - 2520-6761

unemployment and it is calculated as a percentage by dividing the number of unemployed individuals by all individuals currently in the labor force. Unemployment occurs when a person who is actively searching for employment is unable to find work. Unemployment is often used as a measure of the health of the economy. During a period of recession, an economy usually experiences a relatively high unemployment rate. According to the international labor organization of the world workforce was without a job. Unemployment is the condition of being without socially acceptable means of earning a living and employed are persons capable of labor in needs to work or the suitability of what they can do to the need of society. (John A. Garrty, 1978; and Abla Abdul, 2012) youth unemployment is a problem that affects most countries. The ability of youth to engage in productive activities has both social and economic consequences for an economy. Youth unemployment is often higher than the unemployment rate for adult highlighting the concern that many countries face in facilitating the transient from school to work. In developing countries youth faces not only the challenge of obtaining productive employment but also obtaining safe and acceptable job.

\subsubsection{Types of unemployment}

There are four types of unemployment and these are as follows:

1. Frictional unemployment.

2. Structural unemployment.

3. Cyclical unemployment.

4. Seasonal unemployment.

\section{Frictional unemployment}

Finding a job takes time and sometimes the reason people are unemployed is because they are waiting for a job that works for them or taking time to decide finding a job. In addition, it takes time for employers to interview a potential candidate and decided which individuals they want to hire. Frictional unemployment is defined as voluntary unemployment because it results from the time needed too much job. One example of frictional unemployment is voluntary quitting one job and taking time. Frictional unemployment arises because of the constant flow of people between jobs and into and out of labor force. Because the information in the job market is imperfect as it takes time for the employed workers and employers with job vacancies to find each other. The nature of fractional unemployment suggested several ways in which public policy could reduce it. An obvious avenue of attack would be improving public employment service or job fairs where a perspective job candidate talks with a representative of different companies (Kaufman et al., 2007).

\section{Structural unemployment}

Structural unemployment is caused by a mismatch between the need of employers and the skill that a workforce in a country has, (according to Drexel University) for example, a law school in the United States trains more lawyers than the country needs, which can make it difficult for a lawyer to get a job as a lawyer. A lawyer may be able to get a job working at a retail store, but he declines the job because it was not the field of work he was trained for structural unemployment can be caused by geographical problems. For example, individuals who are willing to do construction work might live in a rural area, but the construction job only available in urban areas. Structural unemployment can be reduced by government provision or subsidization of the training programme. With structural unemployment job vacancies and employed workers coexist in the market and in the long run is not easily matched. Unlike fractional unemployment, it tends to be concentrated among certain groups that had been adversely by technological changes, the decline of major industry or the movement of a job to another part of the country (Kaufman and Hotchkiss, 2006).

\section{Cyclical unemployment}

Cyclical unemployment is the type of unemployment that is caused by economic recession and type of unemployment talked about frequently in the news. Cyclical unemployment is because of negative economic growth. In other words, cyclical unemployment is when there is not enough demand to supply jobs for people within a country. This type of unemployment can result in a widespread unemployment in a country. Cyclical unemployment is sometimes called a demand deficient unemployment. It is the result of insufficient aggregate demand in the economy to generate enough jobs for those who seek one. Cyclical unemployment is closely linked to the movement of the economy up and down of the business cycle. Public policy might reduce the extent of cyclical unemployment in several ways (Ibid, 2006). 


\section{Seasonal unemployment}

Seasonal unemployment is when a person is unemployed because certain types of job are only available at a certain time of the year. Seasonal unemployment is simply caused by decreased demand for goods or services during a particular time of seasonal unemployment. It is the most predictable type of unemployment because it happens each year. Seasonal unemployment is similar to demand efficient unemployment in that it is reduced by fluctuations in the demand for labors here, however; the fluctuation can be regularly anticipated and follows a systematic pattern over the course of the year. For example, the demand for agricultural employees declines after the planting season and remains so until the harvest season. Similarly, the demand for production workers falls in certain industries during the season of the year when plants are retooling to handle annual model changes (Bell, D.N., Blanchflower, D.G., 2010).

\subsubsection{Youth unemployment}

Youth unemployment is one of the most critical challenges the world is facing today. Young people make up almost half of the worlds unemployed; despite accounting for only one-quarter of the working population. Youth unemployment is the unemployment of young people defined by the United Nation as 14-28 years old. An unemployed person is defined as someone who does not have a job but is actively seeking work in order to qualify as unemployed for official and statistical measurement the individual must be without employment, willing and able to work. Youth unemployment rate is historically four to five times more than the adult rates in every country in the world. In 2012, youth made up to $40 \%$ of the world unemployed, with a global youth unemployment rate of $12.6 \%$ close to 75 million youth were unemployed worldwide.

In November 2011, the number of youth unemployed in the United Kingdom exceeded one million for the first time in the past 19 years. In Spain, youth unemployment has doubled since 2008 and now stands at 46\%. In the OECD as a whole is million young people are unemployed representing around $\$ 300$ billion in lost wages alone, over a full year. According to O'Higgins (2002), youth unemployment spread UN evenly among young people. The number of individual characteristics and to increase or decrease the like hood that a young person becomes unemployed; few of these are presented here:

1. Teenagers versus young adult: The general picture that emerges is that the unemployment rate tends to fall with age, which is true for the majority of countries with just a few exceptions. In several countries, the highest unemployment rates are recorded by young adults than teenagers and the prime age (25-54).

2. Women versus men: cerebrally speaking, female labor participation rate is far lower than those of young men particularly in developing countries. The most usual activity outside the labor force for young men is education, principal occupation of young women is housework, with female participation level in education being much lower than young man employment opportunities are generally more limited for women than men.

3. Ethnic origin: in almost every country there are differences in the employment figure according to ethnic origins, with the dominant group or groups' general faring better than minority groups.

4. Young people with a disability: a number of studies have noted their lower rate of the labor force participation and higher unemployment rates. The differential in labor markets success between people with and without disabilities seems to increase with age which may in part be attributed to the tendency of disabilities became more severe as people grow older but may reflect the long term effect of unemployment at any early age.

5. Regional disparities: regional variation in the youth unemployment rate correlates with regional variation in the adult rate. This means countries with a high level of regional variation in adult unemployment tend to be characterized by even higher disparities unemployment opportunity for the effect of unemployment at any early age.

\subsubsection{Characteristics of youth unemployment}

O'Higgins (2001) found out that youth unemployment has its own features.

1. Youth unemployment rate is higher than the adult unemployment rate. The most obvious labor market characteristics of youth unemployment are higher than of adult through there are of course few exceptions to this rule in some developed countries.

2. Variation in youth unemployment is closely related to variation in adult unemployment. 
Business Ethics and Leadership, Volume 3, Issue 2, 2019

ISSN (online) - 2520-6311; ISSN (print) - 2520-6761

3. Youth unemployment and labor force participation. O'Higgins (1997) underlined that the rate of participation would influence the level of youth unemployment through its influence of the sizes of labor force participation rate and would imply higher unemployment rate, other things being equal.

\subsubsection{Causes of youth unemployment}

There are multiple and complex causes behind youth unemployment among them, the quality and relevance of education, inflexible labor market and regulations, which in turn create a situation of assistance and dependencies that are the main causes discussed to the following.

A. From education to employment. The quality and relevance of education are often considered as the first roots cause of youth unemployment. In 2010, in 25 out of 27 developed countries, the highest unemployment rate was among people with primary education or less. Although, high education does not guarantee a decent job. For example, in Tunisia $40 \%$ of university graduates are unemployed against $24 \%$ of non-graduates. This affects highly educated young female in particular. In Turkey, the unemployment rate among universityeducated women is more than 3 times higher than that of university educated men; in Iran and United Arab Emirates, it is nearly 3 times and in Saud Arabia it is 8 times. Beyond the necessity to ensure it is accessible to all, education is not adequately tailored to the need of the labor market, which in turn leads to two consequence: the inability for young people to find jobs and the inability for employers to hire the skills they need. Surveys suggest that up to half of all business have open positions for which they are struggling to find suitably qualified people. One global survey found that more than $55 \%$ of employers worldwide believe there is skill crisis as businesses witness a growing mismatch between the skills students learns in the education system and those required in the workplace. For many governments, a key question is how they can bridge this gap and ensure that young people are enquired in the workplace. For many governments, a key question is how they can bridge this gap and ensure that young people are equipped with skill employers are looking for.

B. Youth wage. Wage is likely to have a negative impact on youth unemployment in as much as the higher the relative wage of young workers with respect to those of adult, the more incentive there are to employee adults as opposed to young people.

C. Assistance and dependency. Many countries around the world provide income assistance to support unemployed youth until labor market economic conditions improve. Although this support is strictly related to obligations in terms of active job search and training, it has led to an emerging debate on whether or not it creates dependency among the youth and has a detrimental effect on them. In September 2014, David Cameron announced that he would cut housing and employment benefits for 18-21 years old by 300 to 2300 to reduce dependency on government assistance and redirect funding to targeted programmes for increased learning and training opportunities.

D. Size of the youth labor force. Recently much concern has been expressed about the negative consequence of rapidly growing of youth population in developing countries. The estimated and projected youth labor force is likely until 2010 shows that the number of young people in the labor. Force is likely declined UN industrialized countries, young population is likely to increase in the less developed areas. The growth rate may even accelerate in Africa. While the relative size of the labor force does play a role in the level of youth unemployment, this role out weighted by the effect on the aggregate demand.

\subsubsection{Consequence of youth unemployment}

Youth unemployment has adverse consequences for socio-economic. The following are the consequences of youth unemployment:

A. Business consequence. There are no positive aspects of unemployment; it is really bad for the production of the economy. Unemployment is an economic problem because it represents a waste of valuable resources when unemployment rate group. The economy is an effective throwing away the goods and services that the unemployed workers could have produced the economic less during the periods of high unemployment means that the economy would be producing less than its productivity (ILO, 2006). According to M. Shang (1992), idle human resources resident were a loss of goods and services and therefore, a loss of real income that unemployed resources could have been contributed to the societies wellbeing.

B. Social consequence. Youth unemployment is a major social problem because it causes enormous. Suffering as unemployed workers struggle with reduced income, it is a well-known fact that unemployment, direct relationship with some social problem or antisocial activities increases poverty, social unrest theft, robberies violence potential psychological harms, loss of motivation and increase in crime rate. If people do not have as 
Business Ethics and Leadership, Volume 3, Issue 2, 2019

ISSN (online) - 2520-6311; ISSN (print) - 2520-6761

much disposable income as before as it is very likely that the crime level with the economy will be increased (Mankiew et al., 2002). Early unemployment has a negative effect not only on the future employability of young people but also on their self-esteem, their role in society and can represent a serious economic burden on state finances.

C. Waste of human resources. A high level of unemployment implies that a large number of countries' human resources in most case training and skillful workers are wasting. During a long period of unemployment workers can loss their skills causing loss of human capital. The cost to society could be enormous as hinders of millions of birrs may have been sent training staff only for them to end up being unemployed (Mankiew et al., 2002).

D. Demoralization and hopelessness. High and sustained unemployment could prove to be a source of demoralization and hopelessness in youth unemployment.

E. Lack of confidence. People who have been unemployed for a long time lose confidence in themselves in term of interacting with other speech and even going employed again.

\subsection{Empirical review of literature}

From 1997 to 2007 worldwide youth participation rate decrease will youth in active rate or not from participation in the labor force increased 55.2 to 50.5 and 48.8 to 49.5 percent respectively. This change is explained by increased participation in full-time participation rate for the standard definition of the youth age group 15-24 does not hold true for the age group 15-29 (ILO, 2008).

The force participation rate for this group remains constant over time and indicates the decline in youth labor forces participation rate (for the normal group), which is mainly a passive side effect of long education terms. Namely, post phoning of labor force entry beyond the year that defines youth (ILO, 2008). O'Higgins (1997) says about ill poor force participation in full-time education. He shows that the rate for teenagers (15-19) and youth adult issue that youth face in the labor market (ILO, 2006) in both developing and industrial countries, youth are most susceptible to issue such as, long working hours, work with short-term or informal contract low pay and little or nonsocial protection (ILO, 2004).

\subsubsection{Unemployment in the developing countries}

ILO (2008) reported that the number of unemployed people through the world has 150 million people that they were seeking and available for a work but could not find it. However, a few years earlier the number of unemployed people in the world countries became of a serious and chronic problem in every least developed country. According to ILO 2008 report, unemployment youth amount is particular in Africa. The youth population in Sub-Saharan Africa was estimated at 138 million people in 2002, 2003 with 28.9 million, with 21 percent of the unemployed. This second highest youth unemployment rate in the world on current trends, Sub-Saharan African youth labor force will be even more difficult to accommodate in the future. In fact, the ratio of the youth unemployment to adult unemployment was 3.6 in 1993 and remains virtually unchanged at 3.5 in 2003. Over the last decade the rate of youth participation in employment in Sub-Saharan and Arica rose from $64.4 \%$ to $65.4 \%$ but it dropped on the rest of the world from $58.8 \%$ to $54.7 \%$. The youth labor force in Sub-Saharan Africa is projected to grow by $28.2 \%$ between 2003 and 2005, compared with mire 3.8\% increase in South East Asia and 3.1\% declined industrial economies including the transition phase of economy. SubSaharan Africa is also the only region where adult and youth labor force will grow at a similar rate around $30 \%$ with further adverse repercussion for the youth labor force market.

\subsubsection{Youth unemployment in Ethiopia}

Unemployment in Ethiopia has declined markedly since 1999; both for youth and for the economy as a whole. However while the economy has demonstrated an impressive reduction in unemployment in urban areas and for women unemployment figure remains high - a working paper by Nzingah Broussard. Ohio state university and Geber kidan Teklesillassie university of Sunnex has examined the youth labor market in Ethiopia and provided a comprehensive description of the main characteristics of the youth labor market in Ethiopia. The report provides information on the structure and trends of unemployment or underemployment in Ethiopia and the authors identify important policy inputs in designing government intervention in the labor markets, poverty, reduction strategies and economic growth plans that could help to improve the labor market outcomes of Ethiopian youth. Unemployment among women is also a significant issue, as in Ethiopia display significantly higher unemployment rates than their male counterparts and are often confined to the informal sector. Furthermore, in Ethiopia, there has been significant increase in Education. However, there has not been as 
Business Ethics and Leadership, Volume 3, Issue 2, 2019

ISSN (online) - 2520-6311; ISSN (print) - 2520-6761

much job creation to provide employment opportunities to the newly educated job seekers. Youth unemployment is a problem that affects most countries; the ability of youth to engage in productive activities has both social and economic consequences for an economy.

\section{Description of the Study Area and Methodology}

\subsection{Description of the study area}

Mettu Town is located in Oromia region of inllu aba Bora Zone. Mettu is a market town and located in South Western Ethiopia. This town has altitude and longitude of $818 \mathrm{~N} 35 \mathrm{E} / 8.300 \mathrm{~N} 35.583 \mathrm{E}$ respectively and an altitude of 1605 meters. Mettu Town is situated at the distance of $660 \mathrm{~km}$ from Addis Ababa and it's astronomically location is 3111 North latitude and 295741 East longitude. Mettu Town was founded in 1920 as one of the reformer towns in the region and has administration municipality. The town has a structured plan, which was prepared in 2005. The National Census of Ethiopia (2007) reported that the total population of the town is 41231 out of which 21027 were men and 20204 women. The majority of inhabitants is orthodox Christianity comprising about $47.5 \%$ of the total population and followed by Muslim (around 26\%) and other protestant Muslim also approximately $26 \%$.

\subsection{Methods of data collection and analysis}

\subsubsection{Method of data collection}

Primary data for the research was conducted through personal interviews and well-defined questionnaires. More of the study is conducted by primary data sources through interview and distributing a questionary for the respondents in order to obtain relevant information that would be easier to analyze. The open and closedended method of collecting information instruments are found to be better for youth unemployment data collection hence the questionnaires are prepared in both open and closed-ended format. Secondary data was collected from public documentation. These data are the major sources of information to the researcher because they include: Published document and Report on youth unemployment activity in Ethiopia.

\subsubsection{Source of data}

The researcher has used both primary and secondary data to conduct this research. Primary and secondary data have been collected from the sample of youth unemployed in order to accomplish the research paper, successfully. The primary data has been collected from the sample of 70 youth unemployed in the town. On the other hand, the secondary data for the research was books, unpublished documents, Internet different reports regarding unemployment and youth unemployment and government office such as central statically agency (CSA) and Mettu population youth bureau.

\subsubsection{Methods of data analysis and interpretation}

Data analysis is the most important component of the research study and accordingly, the responses of the respondents have been analyzed using the statistical tools and techniques. Data is processed and analyzed by using different descriptive techniques. The data collected from the source have been organized and classified according to their similarities using tables and percentage.

\subsubsection{Sampling techniques and size}

\subsubsection{Sample size}

As I collected the data from the town regarding the population data in this year (2018) Mettu Town has a young population of 2010. This population is divided into two parts. These are unemployed and employed. Among them, the unemployed are 210 and the employed or economical working age population are 1800. In this case, 70 youth unemployed is taken as the sample size with the consideration of time and cost constraints. The sample size is determined according to Yamane (1967) sample size at 95\% confidence intervals the degree of variability 0.5 and level of precision $9 \%$ sample size was computed as follows;

$\mathrm{n}=\mathrm{N} / 1+\mathrm{N}\left(\mathrm{e}^{2}\right)$

Where $\mathrm{n}=$ sample size;

$\mathrm{N}=$ the targets population;

$\mathrm{E}=$ level of precision $(0.01)$;

$\mathrm{n}=210 / 1+210(0.1)^{2}$; 
$\mathrm{n}=210 / 1+210(0.01)$

$\mathrm{n}=210 / 1+2.1$;

$\mathrm{n}=210 / 3.1$;

$\mathrm{n}=68$. The sample size selected is 70 (seventy).

\subsubsection{Sample technique}

The sampling technique employed to select sample size is systematic Random sampling. The method involves selecting at random from all list of the population (sample from they require a number of subjects for sample 70). The sample of youth unemployed contains subjects with characteristics similar to the population as a whole and we have taken 70 youth unemployed using systematic random sampling.

\section{Data Analysis and Discussion}

\subsection{Demographic characteristics}

\subsubsection{Age of the respondents}

Age is one of the major variables that affect unemployment. As to the sample from the survey conducted, one can extract some correlation between the age and rate of youth unemployment.

Table 1. Age group of respondents

\begin{tabular}{|l|c|c|c|c|}
\hline \multirow{2}{*}{ Age group } & \multicolumn{3}{|c|}{ Total number of unemployed } & \multirow{2}{*}{$\begin{array}{c}\text { Percentage of } \\
\text { unemployment }\end{array}$} \\
\cline { 2 - 5 } & Male & Female & Total & 35.24 \\
\hline $15-20$ & 15 & 10 & 25 & 40 \\
\hline $21-24$ & 12 & 10 & 22 & 24.6 \\
\hline Above 25 & 18 & 5 & 23 & 100 \\
\hline Total & 45 & 25 & 70 & \\
\hline
\end{tabular}

Source: Primary household survey, 2018

As indicated in Table 1, 40 percent of the total respondents were between age group 21-24 sampled was employed. However, 35.24 and 24.6 percent of the respondent's age are between 15-20 and above 25 respectively. The Table reveals that the most productive section of the community, the youth population is highly affected by unemployment problems due to inefficient business and business policy. Generally, when the year of ages increases the rate of unemployment decreases and vice versus. Most of the students who fall their examination are found to be in the age of 15-29, which is most unemployed. In addition, people with the age group 15-29 are found to be more migrants from rural to urban and they are forced to be unemployed due to the lack of skill.

\subsubsection{Sex and marital status of the respondents}

Sex and marital status are the other major factors affecting the rate of unemployment.

Table 2. Sex and marital status of unemployed youth

\begin{tabular}{|c|c|c|c|c|}
\hline \multirow{2}{*}{ Marital status } & \multicolumn{3}{|c|}{ Total number of youth unemployment } & \multirow{2}{*}{$\begin{array}{l}\text { Percentage of youth } \\
\text { unemployment }\end{array}$} \\
\hline & Male & Female & Total & \\
\hline Single & 25 & 15 & 40 & 73 \\
\hline Married & 10 & 20 & 30 & 27 \\
\hline Total & 35 & 35 & 70 & 100 \\
\hline
\end{tabular}

Source: Primary household survey, 2018

As far as sex is concerned unemployment is unevenly distributed between the two sexes. Both male and female are affected by the problems. The account about 50 percent are male and 50 are female of total unemployed. The reason is that they are unable to succeed in their examination thereby becoming subjects of unemployment problem more than the rest ages. As a result, they do not have the chance to be employed in small-scale measure, unless they become employed organized in the group in the form of business cooperatives. When we come to females, they have lower performance, in education and fall from their examination than males. They are not encouraged to attend class by their family and they assume almost the household work. This retards them from being completed in education performance. On the other hand, they are giving less emphasis by employers, government and private. This is because female are considered as physically weak and less capable to do things in comparison to males. They become frustrated with the labor market and remain unemployed for a long period. When we come to marital status the unmarried households, are found to more unemployed 
ISSN (online) - 2520-6311; ISSN (print) - 2520-6761

than of married ones. From the above Tables, $73 \%$ of the total unemployed are single while $27 \%$ of the total unemployed are married.

\subsubsection{Education status of the respondents}

The education level achieved is one of the determinants of unemployment. As a result, we have taken educational status in most variable interest in the study.

Table 3. Educational statuses of the respondents

\begin{tabular}{|l|c|c|c|c|}
\hline \multirow{2}{*}{ Education status } & \multicolumn{3}{c|}{ Total number of unemployed } \\
\cline { 2 - 5 } & Male & Female & Total & \% of unemployment \\
\hline Illiterate & 8 & 5 & 13 & 18.5 \\
\hline First cycle (1-4) & 5 & 6 & 11 & 15.7 \\
\hline Second cycle (5-8) & 3 & 4 & 7 & 10 \\
\hline High school (9-10) & 10 & 8 & 18 & 25.7 \\
\hline Preparatory school (10-12) & 5 & 4 & 9 & 12.8 \\
\hline TVET & 0 & 0 & 0 & 0 \\
\hline University first degree & 4 & 6 & 10 & 14.2 \\
\hline Total & 36 & 34 & 70 & 100 \\
\hline
\end{tabular}

Source: Primary household survey, 2018

As we clear from Table 3, the unemployment rate increases as a person achieves more level of education, then decreases. In contrary to that, a person who achieves more level of education, especially high school and preparatory national Examination fails are usually found to be job selective. As we can read from Table, 25.7 percent of high school completed. Most of the students, who failed the national examination in grade 10, those students, are not only from Mettu town but also from the surrounding areas. Students who come back from those areas do not go back to their home and remain in the town wondering here and there. Thus, the highest unemployment rate possessed by high school dropouts which three characteristics; they are job selective, lack of qualification and rural-urban migration.

Illiterate first cycle and second cycle accounts, 15.7 and 10 percent of total unemployed. The unemployed persons at this level of Education miss job opportunities because they lack the required education level to get a job. An unemployed person whose level of education is the preparatory level of accounted 9 percent, TVET and university first-degree 10 each, while Diploma level 2.8 percent accounted.

\subsubsection{Work experience of the respondents}

Work experience is also one of the most determinants of unemployment. Individual who employed before in government, nongovernment and private organization may have higher opportunities to get using his or her experience. The following Table shows the work experience of the respondents.

Table 4. Work experience obtained by the respondent from organization they employed before

\begin{tabular}{|l|c|c|}
\hline \multirow{2}{*}{ Organizations } & \multicolumn{2}{|c|}{ Respondents } \\
\cline { 2 - 3 } & Frequency & Percentage \\
\hline Government & 4 & 3.275 \\
\hline Non-government & 3 & 2.459 \\
\hline Private & 5 & 4.000 \\
\hline Self-employed & 0 & 0.000 \\
\hline Total & 12 & 9.75 \\
\hline
\end{tabular}

Source: Primary household survey, 2018

As indicated in Table 4, only 9.75 percent of the respondents replied that they are unemployed by obtaining (having) experience from the organization employing before. This because the person developed skills as a result of work which help him or her to find a new job start his or her own business or to perform current work better. This implies as work experience increases, the level of unemployment decreases.

\subsection{Family background of the respondents}

Family background is one of the factors that affects the level of unemployed. Family educational status determines the level of unemployment. 
Table 5. Family education status of respondents

\begin{tabular}{|l|c|c|c|c|}
\hline \multirow{2}{*}{ Education } & \multicolumn{2}{|c|}{ Family } & \multirow{2}{*}{ Total number of unemployment } & \multirow{2}{*}{ Percentage } \\
\cline { 2 - 3 } & Father & Mother & 25 & 35.7 \\
\hline Illiterate & 15 & 10 & 18 & 25,7 \\
\hline First cycle (1-4) & 10 & 8 & 14 & 20 \\
\hline Second cycle (5-8) & 8 & 6 & 4 & 5.5 \\
\hline High school (9-10) & 4 & 0 & 2 & 2.8 \\
\hline Preparatory & 0 & 2 & 0 & 0 \\
\hline TVET & 0 & 0 & 0 & 0 \\
\hline Diploma & 0 & 0 & 7 & 10 \\
\hline University (first degree) & 3 & 4 & 70 & 100 \\
\hline Total & 40 & 30 & & \\
\hline
\end{tabular}

Source: Primary household survey, 2018

As we observe from Table 5, the unemployment with illiterate with first cycle Education level family most account for 61.4 percent of total sample related to employed people. This followed by second cycle 20 percent and high school and university first degree 5.5 and 10 percent respectively. Table rivals that the level of unemployment declines as the level of Education achieved by family rise. In addition to family education level, family occupation status is another factor, that determines the level of unemployment.

Table 6. Family occupational status of the respondents

\begin{tabular}{|l|c|c|c|c|}
\hline \multirow{2}{*}{ Family occupation } & \multicolumn{2}{|c|}{ Family } & \multirow{2}{*}{ Total unemployed } & \multirow{2}{*}{ Percentage } \\
\cline { 2 - 3 } & Father & Mother & 4 & 5.7 \\
\hline Government employed & 3 & 1 & 10 & 14.2 \\
\hline Private (NGO) employee & 5 & 5 & 24 & 34.2 \\
\hline Self-employed & 15 & 9 & 32 & 45.7 \\
\hline Farmer & 30 & 2 & 7 & 100 \\
\hline Total & 53 & 17 & \\
\hline
\end{tabular}

Source: Primary household survey, 2018

According to the above Table, 45.7 percent of the unemployed respondents are farmers, which are followed by self-employed and private (NGO) employees by 34.2 and 14.2 percent respectively. The total number of the unemployed respondents with government employee family is low as this is only 5.7 percent from the total sample of unemployed people because most of the government employees are more educated, gaining more work experienced and can search job easy for their child.

\subsection{Cause and impact of youth unemployment}

Many factors including mainly inefficient business and business policy are the cause of concern to rise unemployment in Mettu town number of respondents forwarded the explanation out of which the major ones are discussed under this section.

Table 7. The major cause of youth unemployed in respondents

\begin{tabular}{|l|c|c|}
\hline \multirow{2}{*}{\multicolumn{1}{c|}{ Problems }} & \multicolumn{2}{c|}{ Respondents } \\
\cline { 2 - 3 } & \multicolumn{2}{c|}{ Frequency } \\
\hline Inefficient business environment & 20 & 28.57 \\
\hline Lack of appropriate business policy & 12 & 17.14 \\
\hline Lack of education & 09 & 12.86 \\
\hline Lack of training & 10 & 14.29 \\
\hline Lack of capital & 12 & 17.14 \\
\hline Lack of network & 07 & 10 \\
\hline Total & 70 & 100 \\
\hline
\end{tabular}

Source: Primary household survey, 2018

In the Table above, the main cause of youth unemployment is inefficient business environment $(28.57 \%)$ followed by lack of appropriate business policy (17.14\%) and lack of capital (17.14\%) respectively.

Table 8 . The reason for the respondent's unsuccessfulness in finding a job

\begin{tabular}{|l|c|c|}
\hline \multicolumn{1}{|c|}{ Reasons } & Total number of unemployment & Percentage \\
\hline Lack of information & 20 & 28 \\
\hline Lack of education & 35 & 50 \\
\hline Lack of experience & 10 & 14.2 \\
\hline Low wage & 5 & 7 \\
\hline Total & 70 & 100 \\
\hline
\end{tabular}

Source: Primary household survey, 2018 
ISSN (online) - 2520-6311; ISSN (print) - 2520-6761

The above Table shows that most of the employed respondents failed to get a job because of lack of information and lack of education which accounts 28 and 50 percent from the sample taken; 14.2 and 7 percent of the unemployed respondents replied that lack of experience and low wage existing in the market protect them from successfully getting a job.

Table 9. Respondents whether they actively seek work as employee persons or not

\begin{tabular}{|l|c|c|}
\hline \multicolumn{1}{|c|}{ Item } & Number of employed respondents & Percentage \\
\hline Did you actively seek work as an unemployed person? & & 71.4 \\
\hline Yes & 50 & 28.5 \\
\hline No & 20 & 100 \\
\hline Total & 70 & \\
\hline
\end{tabular}

Source: Primary household survey, 2018

The above Table indicates that most of the respondents actively seek work as unemployed persons, which accounts for 71.4 percent of total unemployed respondents. This is due to the government policies inducing individual and group to actively seek their own work reeling from the problem of unemployment using different mechanism like small-scale microenterprise. The remaining 28.5 percent of unemployed respondents are unsuccessful in actively seeking work as unemployed persons because they are not interested with the existing labor market and not ready to enter the labor force.

Table 10. Respondents whether they try to find a job as self-employed persons or not

\begin{tabular}{|l|c|c|}
\hline \multicolumn{1}{|c|}{ Item } & Number of employed & Percentage \\
\hline Did you try to find a job as a self-employed person? & & 68.5 \\
\hline Yes & 48 & 31.4 \\
\hline No & 22 & 100 \\
\hline Total & 70 & \\
\hline
\end{tabular}

Source: Primary household survey, 2018

Table 10 shows that 68.5 percent of the total youth unemployed respondents did try to find a job as a selfemployed person. This because the unemployed youth in the town are students who failed grade 10 examination and grade 12 examination and they may be migrant from surrounding areas who lack to as well as moral they lose in the community protect them try to find a job as a self-employed person.

Table 11. Respondents whether they find a job in micro- and small scale enterprise

\begin{tabular}{|l|c|c|}
\hline \multicolumn{1}{|c|}{ Items } & \multirow{2}{*}{ Number of unemployed } & \multirow{2}{*}{ Percentage } \\
\hline Did you find a job in micro- and small scale enterprise & 50 & 71.4 \\
\hline Yes & 20 & 28.5 \\
\hline No & 70 & 100 \\
\hline Total & & \\
\hline
\end{tabular}

Source: Primary household survey, 2018

The above Table indicates that most of the respondents are not finding a job in micro- and small scale enterprise, which accounts 28.5 percent of the total sample size of youth unemployed respondents. It is noteworthy that the youth find a job in a government institution and they do not prefer the first MSSE. The remaining 71.4 percent of the total unemployed respondents are finding a job in the second best alternatives of MSSE.

\subsection{Extent of unemployment in Mettu Town}

When we came to assess the recent situation of unemployment in Mettu Town, it is a serious problem coupled with population growth and increased poverty. In Mettu Town, this problem gives private and social problems in society such as increased crimes, poverty, alcoholism, and prostitution.

Table 12. The extent of unemployment from the total sample size

\begin{tabular}{|l|c|c|}
\hline \multicolumn{2}{|c|}{ Number of unemployed } & Percentage \\
\hline Male & 55 & 78.5 \\
\hline Female & 15 & 21.4 \\
\hline Total & 70 & 100 \\
\hline
\end{tabular}

Source: Primary household survey, 2018

According to the survey result, 78.5 percent of the respondents are male and the remaining 21.4 percent are female.

\section{Conclusion and Recommendations}

\subsection{Conclusion}

It is obvious that Mettu town is located in a remote isolated area and suffering from many hidden problems. Unemployment is one of the biggest challenges in the town. Data related to unemployment indicates that the 
unemployment rate in the town is increasing tremendously from year to year and consequently even the total unemployed numbers of male and female also increased. The problem of unemployment unevenly distributed between both male and female in each year. Both the primary and secondary data are shown in the results and analysis part of the study. Inefficient business environment and adequate business policy are the main cause of concern for growing unemployment among youth in Ethiopia. However, other factors like, education, networking, and information are also responsible partially for unemployment.

With respect to work experience, it is found that experienced persons have a better chance to avail any kind of employment opportunity rather than non-experienced young persons. It is also expelled that the experience of the persons has negative relationship to unemployment. The other causes of unemployment in the regions are lack of training, lack of capital, rural-urban migration, etc. There is general agreement that training programmes appear to be less useful in times of recession, particularly when compared with other forms of programmes such as employment subsidies; training programmes are performed better when they are instituted during periods of economic expansion (Betcherman et al., 2004 and McVicar \& Podivinsky, 2010). In a metaanalysis by the same authors (Kluve \& Schmidt, 2002) is found an analogously signed effect of GDP growth, however in this case - and with a smaller sample size - the effect was not statistically significant. Lechner \& Wunsch (2009) also find a positive relationship between programme effectiveness and the National unemployment rate in Germany although the relationship disappears when they control for regional (rather than national) unemployment rates. Since it is the local labour market, which is likely to have a more direct impact on post-programme outcomes, one wonders how to interpret this result.

\subsection{Recommendations}

Appropriately, the allocation of resources among the society is the main agenda of the respective government in order to maximize social welfare. The population and migration from rural to urban area are at the stage of galloping in Ethiopia. Ethiopia is a fast growing economy particularly in the continent of Africa and recorded a speedy growth rate during Growth and Transform economy I and II. However, the government of Ethiopia must have to concentrate on the policy perspectives in order to provide more employment opportunities to youth. On the basis of assessment and observation at ground level unemployment problems in the country the government must consider the following macro level policy to overcome with current burning issues of unemployment in Ethiopia.

$>$ As observed, there is plenty of business opportunities in the country and the federal government of Ethiopia must make a congenial atmosphere to attract foreign direct investors and fully liberalize economic policy at the earliest in order to increase the employment opportunities.

$>$ There is a need for adopting transparent and growth-oriented business policy from the bottom to the top level by the government with the consultation of stakeholders and community concerned.

$>$ The government also adopts the policy of labour-intensive technologies in the field of small scale and cottage industries to provide more employment opportunities for rural unskilled labor.

$>$ The government must have to strengthen the institutions of property rights regime for appropriate allocation of resources among the society.

$>$ Human capital-centered investment is required in the country to explore more opportunities to come across the world.

$>$ The government should also have to sponsor self-employment guaranties schemes in order to reduce unemployment among skilled labor.

$>$ Balanced development is important for accelerating employment opportunities in the country one side and restrict migration from rural to urban another side.

$>$ Import substitution is one of the options for the federal government to save more foreign currency and provide more employment opportunities within the territory of the country.

$>$ Priorities must be given on research and transfer of technology with bit investment in the business of agricultural and rural development.

Technological interferences parallel to other countries are important in every field of the business economy.

\section{List of abbreviations}
AIDS - Acquire Immune Deficiency Syndrome;
CSA - Central Statics Agency;
HIV - Human Immune Virus; 


\section{References}

1. Abla, Abdul Hameed Bokhari (2012). Entrepreneurship as a Solution to Youth Unemployment in the Kingdom of Saudi Arabia. American Journal of Scientific Research, 87, 120-134.

2. Bassanini, A. \& Duval, R. (2006). Employment Patterns in OECD Countries: Reassessing the Role of Policies and Institutions, OECD Social, Employment and Migration Working papers no. 35, OECD, Paris.

3. Barton, Dominic, Farrell, Diana and Mourshed, Mona (2013). Young people can't find jobs. Yet employers can't find people with the right entry-level skills. How can we close this gap Education to employment designing system that works? Jan 2013 Report.

4. Bell and Blanch Flowers (2010). Youth unemployment in Europe and the United States. Nordic Economic Policy Review 1.

5. Bell, D.N., Blanchflower, D.G. (2010). Youth unemployment: Déjà Vu?. IZA Discussion Papers 4705, Institute for the Study of Labor (IZA), Bonn.

6. Bertola, G., Blau, F.D. and Kahn, L.M. (2007). Labor market institutions and demographic employment patterns. Journal of Population Economics, 20(4), 833-867.

7. Betcherman, G., Olivas, K., Dar, A. (2004). Impacts of active labor market programs: New evidence from evaluations with particular attention to developing and transition countries. Social Protection Discussion Paper no. 0402, World Bank, Washington, D.C.

8. Central Statistical Agency of Ethiopia (1984). National population census, Addis Ababa Ethiopia. Report.

9. Central Statistical Agency of Ethiopia (1994). National population census, Addis Ababa, Ethiopia. Report.

10.Central Statistical Agency of Ethiopia (2005). Youth population project in Ethiopia. Report.

11.Central Statistical Agency of Ethiopia (2007). National population census, Addis Ababa, Ethiopia. Report.

12.Denu, B., Tekeste, A., and Deijl, V.D.H. (2005/07). Characteristics and determinants of youth unemployment, underemployment and inadequate employment in Ethiopia. Employment Strategy Papers.

13.Garrty, John, A. (1978). Unemployment in History: Economic Thought and Public Policy. New York Harper and Row 1978. Pp. xii, 273.

14.Gugecello, Lorenzo and Roast, Furio (2007). Child labor and youth unemployment: Ethiopian country study, March. Report.

15.International Labour Organization (2002). Worldwide growing concern of youth unemployment. Report.

16.International Labour Organization (2004). Population growth impact for the expansion of unemployment worldwide. Report.

17.International Labour Organization (2006). World work force without job. Report.

18.International labour Organization (2003). Active labor market policies in support of Ethiopians sustainable development and poverty reduction program. Ethiopia employment mission report Addis Ababa, ILO.

19.International labour Organization (1990). World employment and unemployment report, Geneva.

20.Jimeno, J.F. \& Rodriguez-Palenzuela, D. (2002). Youth unemployment in the OECD: Demographic shifts, labour market institutions, and macroeconomic shocks. ECB Working paper no. 155, ECB: Frankfurt.

21.Kaufman, B.E. \& Hotchkiss, J. L. (2006). The Economics of Labor Markets. Mason, USA: Thomson, NorthWestern, Seventh edition.

22.Kluve, J. \& Schmidt, C. M. (2002). Active policy evaluation: Problems, methods and results. Economic Policy, 17(35), 410-448.

23.Lechner, M. and Wunsch, C. (2009). Are training programmes more effective when unemployment is high? Journal of Labor Economics, 27(4), 653-692.

24.Mankiw, N.G. (2002). The Inexorable and Mysterious Tradeoff between Inflation and Unemployment. The Economic Journal, 111(471), 45-61.

25.Mettu youth office (2007). Educated employees between male and female of town. Report.

26.Neumark, David, and Wascher, William (2004). Minimum Wages, Labor Market Institutions, and Youth Employment: A Cross-National Analysis. Industrial and Labor Relations Review, 57(2, January), 223-246.

27.O'Higgins, N. (2012). This Time Its Different? Youth labour markets during 'The Great Recession'. Comparative Economic Studies, 54(2), 395-412.

28.O'Higgins, N. (2001). Youth Unemployment and Employment: A Global Perspective. Geneva: ILO.

29.Scarpetta, S., Sonnet, A. and Manfredi, T. (2010). Rising youth unemployment during the crisis: How to prevent negative long-term consequences on a generation? OECD Social, Employment and Migration Working Papers No. 106.

30.Todaro, M. and Smith, S. (2003). Economic development ( $8^{\text {th }}$ Edition). Addison Wesley, United States.

31.World Bank (2002). The federal democratic republic of Ethiopia developing report to promote growth, sector report No 23294 and Washington D.C. 